transport of valuable thoroughbred stallions. Although bull semen can be stored far better than stallion semen, there is reason to believe that "germ cells age and thus become physiologically less vigorous, and that their senility may be one of the main causes of embryonal mortality in both mammals and birds". Dr. Nalbandov stresses the importance of timing matings or insemination in domestic animals and in man "in such a way as to immunize the deleterious effects of the ageing of the ova and sperm cells".

Dr. Nalbandov's aim has been to give as full an account as possible of the "comparative reproductive physiology of domestic animals, laboratory animals and man", and the book he has written is the most complete work on this subject which the reviewer has, as yet, encountered. The various chapters contain many references to articles and books which provide departure points for further reading on these subjects. Both these new books should become standard works on their respective subjects.

KENNETH WALKER

\section{THE ARRHYTHMIAS}

\section{Rhythmusstörungen des Herzens}

Systematik-Ursache und Klinische BedeutungTherapie. Von Prof. Konrad Spang. Mit beiträgen : Die Morphologie des Reizleitungssystemes, ihre Orthologie und Pathologie. Von Prof. W. Doerr. Physiologie der Herzirregularitäten. Von Dr. W. Trautwein. Pp. xvi +548 und ein Tafelanhang mit 228 Abb. (Stuttgart: Georg Thieme Verlag, 1957.) 148 D.M.

7 HE length of this book on a relatively circumscribed subject may at first alarm the reader, but he will be quickly reassured when he begins to study it, for it is clearly arranged and the style is lucid.

The author has set himself the task of re-awakening interest in the arrhythmias. After the initial enthusiasm following the appearance of Sir Thomas Lewis's book and that of Wenckebach and Winterberg, interest has lagged, since only a few arrhythmias are really of clinical importance. The author believes them to be often of greater clinical importance than is sometimes recognized to-day, but at the same time admits that in many cases the only reward of laborious study may be a better understanding of the disordered physiology.

To a British reader the collection of illustrative electrocardiograms at the back of the book, divorced from the text, is a drawback, since inclusion of a suitable illustration on the same page as the text makes for clearer exposition. On the other hand, diagrammatic representation of the mechanism of many of the complicated arrhythmias, such as parasystole, is included in the text and the notation of these diagrams could scarcely be improved, explaining at a glance what neither text nor electrocardiogram could convey simply. The diagrams of abnormal spread of conduction through the heart are also very clear and helpful.

The nower theories of the genesis of some of the arrhythmias, such as atrial fibrillation, are fully discussed. Rhythm changes during spocial cardiac investigations and during operations on the heart under hypothermia are briefly touched on. In addition, the chapters on treatment include more recent methods, such as the cardiac pace-maker and the defibrillator.

This book attempts to wed academic interest in the arrhythmias to fuller understanding of their clinical importance, and in this it largely succeeds.

J. P. D. Mounsey

\section{TREATISE OF ZOOLOGY}

\section{Traité de Zoologie}

Anatomie, Systématique, Biologie. Publié sous la direction de Prof. Pierre-P. Grassé. Tome 13: Agnathes et Poissons-Anatomie, Éthologie, Systématique. Premier Fascicule: Pp. viii +924. Deuxième Fascicule : Pp. viii +925-1812. Troisième Fascicule : Pp. vii $+1813+2758$. (Paris: Masson et Cie., 1958.) Chaque fascicule, broché, 12,000 francs; cartonné, 13,000 francs.

$\mathbf{T}$ is ten years since the first volume (Vol. 11 in the series) of the "Traité de Zoologie" appeared, and now we have to welcome Vol. 13, the ninth to be published, which is devoted to the Agnatha and Pisces. The total number of volumes in the series is to be eighteen, so that approximately half the work has now been published although there may be rather less to come as some of the larger classes have already been dealt with. Zoologists the world over have come to know what to expect and to look forward to new additions to the treatise. The present volume, with its 2,758 pages, is so large that it has been divided into three almost equal fascicles, each as large as an ordinary volume, containing 924,888 and 946 pages, respectively. As in all previous volumes, this one is generously furnished with illustrations which form an important part of the work.

The last text-figure is numbered Fig. 1889, but this is misleading and there has been some confusion in numbering, for Fig. 219 on p. 419 is followed on p. 434 by Fig. 245, and Fig. 1043 occurs on p. 1453 and again on p. 1471 , so that the actual number is 1865. There are six plates in full colour. This, as in former volumes, does not give a fair impression of the wealth of illustrations, for a number of the figures contain several drawings which may even be on separate pages ; for example, Fig. 378 occupies the whole of pp. 588 and 589 and nearly all of p. 590, Figs. 81 and 82 take up five complete pages and the best part of two more. These last two figures furnish excellent examples of a combination of line and colour, not common in text-books, but which in these and twentyfive others has been employed with telling effect. The great majority of the figures are line-blocks or halftone or a combination of the two, and are on the whole very good although a few half-tones, for example, Figs. 720, 849, 1474 would be much improved if the background were cut out and the impressions were deeper. It is a pity that in the main systematic part (Fascicle 3) so many of the attractive illustrations give no indication of the magnification or reduction, nor is the size stated in the text. There is a certain lack of consistency in nomenclature, for example, sometimes Lepisosteus is used (deliberately) and sometimes Lepidosteus; sometimes Scylliorhinus and at others Scyllium.

Twenty-two authors, fifteen of them from Paris and each a specialist in his own field, contribute to the volume, thus ensuring an authoritative and up-to-date treatment. It has been customary for the authors to be chosen from French-speaking zoologists, but an 